Al IBTIDA 3 (2): 241-252

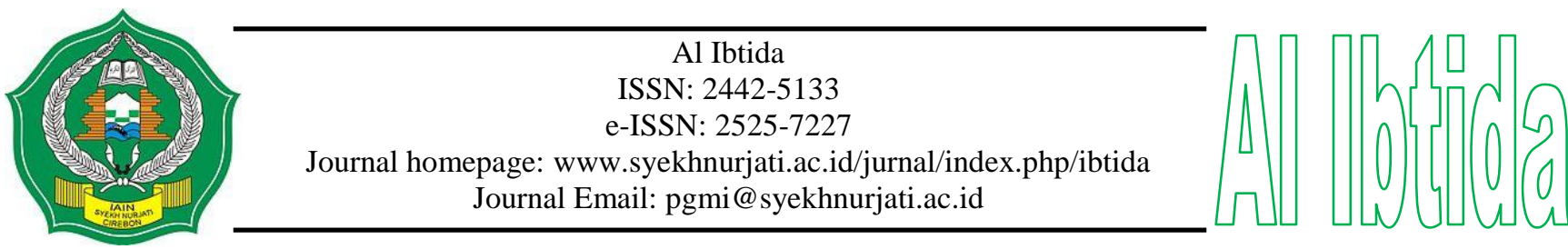

\title{
PENGARUH PENGGUNAAN MEDIA GAMBAR SKETSA TERHADAP HASIL BELAJAR MENULIS KARANGAN DESKRIPSI SISWA KELAS V MIN KOTA CIREBON
}

\author{
Nurbandiah* \\ Jurusan PGMI, FITK, IAIN Syekh Nurjati Cirebon \\ Email: diah55@yahoo.co.id \\ Syibli Maufur* \\ *Jurusan PGMI, FITK, IAIN Syekh Nurjati Cirebon \\ Email: cinta_ayah@rocketmail.com
}

\begin{abstract}
Abstrak
Pada umumnya, siswa mengalami hambatan ketika diberi tugas oleh guru untuk menulis. Mereka mengalami kesulitan dalam menyusun kalimat dan kurang menguasai tata bahasa. Kesulitan-kesulitan tersebut menyebabkan mereka tidak mampu menyampaikan pikiran dan gagasan dengan baik sehingga peserta didik menjadi enggan untuk menulis. Dalam pelajaran Bahasa Indonesia sering kali pembelajaran menulis sangat menjenuhkan. Pada pelaksanaan KBM, guru memberikan tugas kepada siswa untuk menulis karangan tanpa memberikan penjelasan. Padahal guru merupakan faktor terpenting dalam keberhasilan KBM. Jika dilihat dari hasil belajar siswa kebanyakan nilai rata-rata ketuntasan menulis siswa yaitu 70, padahal Kriteria ketuntasan minimal (KKM) untuk mata pelajaran bahasa Indonesia yang ditetapkan oleh sekolah adalah 75, ini kemungkinan karena anak-anak yang kurang minat dalam pelajaran Bahasa Indonesia khususnya pembelajaran menulis karangan, dan bisa juga karena faktor kurangnya pengggunaan media.

Penelitian ini bertujuan untuk memperoleh data respon siswa terhadap media gambar sketsa di MIN Kota Cirebon, memperoleh data hasil belajar menulis karangan deskripsi serta pengaruh media gambar sketsa terhadap hasil belajar menulis karangan deskripsi di MIN Kota Cirebon. Metode yang digunakan dalam penelitian ini adalah eksperimen kuantitatif dengan jenis kuasi eksperimen. Dalam kuasi eksperimen terdapat dua kelas yang diteliti yaitu kelas eksperimen yang diberi perlakuan dan kelas kontrol yang tidak diberi perlakuan. Desain penelitian yang digunakan adalah Nonequivalent Control Group Design. Populasi dalam penelitian ini adalah semua siswa MIN Kota Cirebon sebanyak 278 dan menggunakan teknik purposive sampling
\end{abstract}


yaitu kelas VA dan VB sebanyak 41 siswa. Alat pengumpulan data pada penelitian ini menggunakan lembar tes dan angket.

Hasil penelitian menunjukan bahwa terdapat pengaruh yang signifikan pada hasil belajar menulis karangan deskripsi. Hal ini Berdasarkan dari nilai $\mathrm{R}$ Square sebesar 0,568 (kuadrat dari koefisien korelasi 0,754). Dari nilai tersebut dapat diartikan bahwa $56,8 \%$ pengaruh variable x (media gambar sketsa) terhadap variable y (hasil belajar) sedangkan sisanya dipengaruhi oleh faktor lain. Pada hasil uji regresi di peroleh hasil uji t hitung sebesar 5,002 dengan nilai signifikan sebesar 0,000. Karena nilai signifikan lebih kecil dari 0,05 dan t hitung $(5,002)$ lebih besar dari t tabel (2.10982) maka dapat disimpulkan bahwa Ho ditolak, artinya bahwa ada pengaruh media gambar sketsa terhadap hasil belajar menulis karangan deskripsi Sedangkan sisanya dipengaruhi oleh faktor lain.

Kata Kunci: sketsa, karangan, deskripsi, hasil belajar.

\begin{abstract}
In generally, students have obstruct while the teacher give a task to write. They have a trouble in arranged the sentence and unsufficiently control the grammar. That a difficult caused they can't pass on thinks and ideas with every consideration so participant to be lazy to write. In Indonesian study learning writes really saturated. On KBM'S performing, teacher gives task to student to write composition without gives explanation. Eventually teacher is primary factor in make KBM'S success. If we see from student's studying result mostly student's write average value is 70 , eventually minimal thoroughness Criterion (KKM) for specified indonesian subject by schooled is 75, this possible because children which insufficiently tutorial deep Indonesian in particular learning writes composition, and can also since its reducing factor media purpose.

This research intent to get student's response data toward sketches pictured media at MIN Cirebon's City, getting the data of the result of to write description composition study and the influence of the sketch draw's media toward write description composition study at MIN Cirebon's City. The method that use in this research is quantitative experiment with my type experiment attention. In experiment attention are have two class that analyze there are experiment class that given by attention and control class that don't give attention. Observational design that use is Nonequivalent Control is Design's Group. Population in observational are all MIN'S students Cirebon's City as much 278 and use purposive is sampling technique there are class VA and VB as much 41 students. Data collecting tool on this reserach are use essay sheet and questionnaire.

The result of this research show that there is a significance influence to write description composition. It is based on score $R$ Square is 0,568 (square of correlation coefficient 0,754). From that score it's mean that 56,8\% variable's influences $x$ (sketches pictured media) toward variable y (learner's result) meanwhile its rest regard by other factor. On the result of regression tests to get the result of the quiz t is 5,002 by signifikan score is 0,000. Because signifikan's point smaller of 0,05 and $t$ computing is $(5,002)$ more high of $t$ table (2. 10982) so we can concluded that Ho is refused, its mean that there is
\end{abstract}


the influence of sketch draws media toward the result of studying writes description composition. Whereas its rest influenced by other factor.

Key word: sketch, composition, description, learning outcomes.

\section{PENDAHULUAN}

Keterampilan berbahasa dalam kurikulum sekolah biasanya mencangkup empat aspek yaitu keterampilan menyimak, keterampilan berbicara, keterampilan membaca dan keterampilan menulis. Menulis adalah suatu kegiatan menuangkan ide atau gagasan dalam bentuk tulisan, yang ditulis dalam kertas. Suparno (Dalman, 2015: 4) menjelaskan bahwa menulis dapat didefenisikan sebagai suatu kegiatan penyampaian pesan (komunikasi) dengan menggunakan bahasa tulis sebagai alat atau medianya. Menulis yang ada di sekolah terutama dalam pembelajaran Bahasa dan Sastra Indonesia yaitu menulis karangan.

Dalam pelajaran Bahasa Indonesia sering kali pembelajaran menulis karangan sangat menjenuhkan. Peserta didik mengalami hambatan ketika diberi tugas oleh guru untuk menulis. Mereka mengalami kesulitan dalam menyusun kalimat dan kurang menguasai tata bahasa. Kesulitan-kesulitan tersebut menyebabkan mereka tidak mampu menyampaikan pikiran dan gagasan dengan baik sehingga peserta didik menjadi enggan untuk menulis.

Pada pelaksanaan KBM, guru memberikan tugas kepada siswa untuk menulis karangan tanpa memberikan penjelasan. Padahal guru merupakan faktor terpenting dalam keberhasilan KBM. Guru dituntut menggunakan media yang tepat untuk mencapai kompetensi pembelajaran menulis yang akan dicapai siswa.

Berdasarkan hasil observasi dan wawancara pada hari Sabtu, 08 Februari 2016 yang dilakukan dengan wali kelas sekaligus guru mata pelajaran Bahasa Indonesia kelas V MIN Kota Cirebon yaitu Bapak Ali Muhidin, S.Pd. SD mengatakan bahwa "jika dilihat dari hasil belajar siswa kebanyakan nilai rata-rata ketuntasan menulis siswa yaitu 70, padahal Kriteria ketuntasan minimal (KKM) untuk mata pelajaran bahasa Indonesia yang ditetapkan oleh sekolah adalah 75. Ini kemungkinan karena kurangnya minat siswa dalam pelajaran Bahasa Indonesia khususnya pembelajaran menulis karangan dan kurangnya pengggunaan media dalam pembelajaran menulis karangan".

Dalam proses pembelajaran, media adalah salah satu unsur terpenting dalam keberhasilan pembelajaran. Arsyad (2013: 3) menjelaskan bahwa dalam proses belajar mengajar ada dua unsur yang amat penting, yaitu metode mengajar dan media pembelajaran. Lebih lanjut Hamalik mengemukakan bahwa pemakaian media pembelajaran 
dalam proses belajar mengajar dapat membangkitkan keinginan dan minat yang baru, membangkitkan motivasi dan rangsangan kegiatan belajar bahkan membawa pengaruh psikologis terhadap siswa yang berpengaruh pula pada hasil belajarnya.

Media pembelajaran mempunyai peranan yang sangat penting dalam proses belajar mengajar. Disamping dapat menarik perhatian siswa, media pembelajaran juga dapat menyampaikan pesan yang ingin disampaikan dalam setiap mata pelajaran. Dalam pembelajaran di sekolah, guru dapat menciptakan suasana belajar yang menarik perhatian dengan memanfaatkan media pembelajaran yang kreatif, inovatif dan variatif, sehingga pembelajaran dapat berlangsung dengan mengoptimalkan proses dan berorientasi pada hasil belajar belajar.

Sudjana \& Rivai dalam Arsyad (2013: 28) mengemukakan manfaat media pengajaran dalam proses belajar siswa, yaitu:

1. Pengajaran akan lebih menarik perhatian siswa sehingga dapat menumbuhkan motivasi belajar.

2. Bahan pengajarakan lebih jelas maknanya sehingga dapat lebih dipahami oleh siswa dan memungkinkannya menguasai dan mencapai tujuan pengajaran.

3. Metode pengajar akan lebih bervariasi, tidak semata-mata komunikasi verbal melalui penuturan kata-kata oleh guru.

4. Siswa lebih banyak melakukan kegiatan belajar sebab tidak hanya mendengarkan uraian guru, tetapi juga aktivitas lain seperti mengamati, melakukan mendemonstrasikan, memerankan dan lain-lain.

Kriteria pemilihan media harus sesuai dengan taraf berpikir peserta didik. Demikian pula dalam pembelajaran menulis karangan di sekolah. Penggunaan media gambar dirasakan sangat tepat untuk membantu siswa dalam keterampilan menulis. Dengan melihat gambar, siswa dapat menarik isi kesimpulan dari gambar tersebut, kemudian dapat menguraikan dalam bentuk tulisan. Salah satu media yang dapat digunakan guru dalam upaya meningkatkan prestasi mengarang siswa adalah media gambar sketsa. Tarigan (2012: 33) menjelaskan bahwa media gambar sketsa adalah gambar yang sederhana, atau draft kasar yang melukiskan bagian-bagian pokoknya tanpa detail. Melalui media sketsa siswa akan mampu meningkatkan kemampuan menulis karangan deskripsi, karena media sketsa dapat menggambarkan sebuah objek tertentu yang akan dibuat oleh siswa ke dalam karangan deskripsi. Oleh karena itu, media sketsa ini merupakan cara yang efektif guna mempermudah siswa dalam menulis karangan lebih mudah dan lebih menyenangkan. 
Berdasarkan uraian di atas, media gambar sketsa memiliki peranan yang sangat penting dalam proses pembelajaran khususnya mata pelajaran bahasa Indonesia sub pokok bahasan menulis karangan deskripsi, sehingga dalam penelitian ini penulis mengambil judul "Pengaruh Penggunaan Media Gambar Sketsa Terhadap Hasil Belajar Menulis Karangan Deskripsi Siswa Kelas V MIN Kota Cirebon”.

\section{METODE PENELITIAN}

Penelitian ini menggunakan desain penelitian kuasi eksperimen Nonequivalent Control Group Design.

$$
\begin{array}{ccc}
\mathrm{O}_{1} & \mathrm{X} & \mathrm{O}_{2} \\
\mathrm{O}_{3} & & \mathrm{O}_{4}
\end{array}
$$

Keterangan:

$\mathrm{O}_{1} \& \mathrm{O}_{2}=$ kedua kelompok tersebut diobservasi dengan pretest untuk mengetahui hasil belajarnya.

$\mathrm{X}=$ Treatmen. Kelompok atas sebagai kelompok eksperimen diberi treatment, yaitu pembelajaran menggunakan media sketsa, sedangkan kelompok bawah merupakan kelompok control, pembelajaran tidak menggunakan media sketsa. Pengaruh pembelajaran dengan sketsa $\mathrm{O}_{2}-\mathrm{O}_{4}$.

$\mathrm{O} 2$ = kelas Eksperimen yang di beri perlakuan dengan menggunakan media sketsa.

$\mathrm{O} 4$ = kelas kontrol yang tidak diberi perlakuan dengan menggunakan media sketsa. (Sugiyono, 2015: 116)

Sugiyono (2015: 117) menyatakan bahwa populasi adalah wilayah generalisasi yang terdiri atas obyek/subyek yang mempunyai kualitas dan karakteristik tertentu yang ditetapkan oleh peneliti untuk dipelajari dan kemudian ditarik kesimpulannya. Dalam penelitian ini populasi seluruh siswa MIN Kota Cirebon tahun ajaran 2015/2016 yang berjumlah 278 siswa. Sementara itu pengambilan sampel dilakukan dengan menerapkan prinsip purposive sampling atau sampel yang bertujuan. Purposive sampling adalah teknik penentuan sampel dengan pertimbangan tertentu dikarenakan kemampuan peneliti, tenaga dan materi yang terbatas. Sampel dalam penelitian ini adalah kelas V yang berjumlah 41 siswa.

Teknik pengumpulan data yang digunakan pada penelitian ini adalah menggunakan teknik pengumpulan data sebagai berikut : (1) Angket atau disebut juga kuesioner adalah sebuah daftar pertanyaan yang harus diisi oleh orang yang akan diukur (responden). Dengan angket ini orang dapat diketahui tentang keadaan/data diri, pengalaman, pengetahuan sikap atau pendapatnya, dan lain-lain. (Arikunto, 2012: 194). (2) tes adalah suatu alat atau prosedur yang sistematis dan objektif untuk memperoleh data-data atau keteranganketerangan yang diinginkan tentang seseorang dengan cara yang boleh dikatakan tepat dan 
cepat (Arikunto, 2012: 46). Tes ini berupa tes kognitif yaitu soal essai yang digunakan untuk mengetahui hasil belajar siswa Kelas V MIN Kota Cirebon.

Sedangkan teknik analisis data yang digunakan dalam penelitian ini adalah analisis regresi sederhana dengan menggunakan bantuan software SPSS 21,00. Penggunaan software SPSS ini dimaksudkan agar dapat mempermudah perhitungan dalam melakukan pengolahan data sehingga data diperoleh yang sesuai dan akurat serta tepat dengan yang seharusmya terjadi atau didapatkan di lapangan (tempat penelitian). (Sugiyono, 2015: 49).

Untuk mengetahui ada atau tidaknya pengaruh, peneliti menggunakan Uji determinasi. Uji determinasi ini untuk mengetahui besar kecilnya sumbangan variabel $\mathrm{X}$ terhadap Y, dapat ditentukan dengan rumus koefisien determinan sebagai berikut:

$$
\mathrm{KP}=\mathrm{r}^{2} \times 100 \%
$$

Dimana: $\quad \mathrm{KP}=$ Nilai koefisien determinan $\mathrm{r}=$ Nilai koefisien korelasi (Riduwan, 2013: 139).

\section{HASIL DAN PEMBAHASAN}

1. Hasil Belajar Kelas Kontrol dan Kelas Eksperimen

Gambar 1

Hasil Belajar Kelas Kontrol

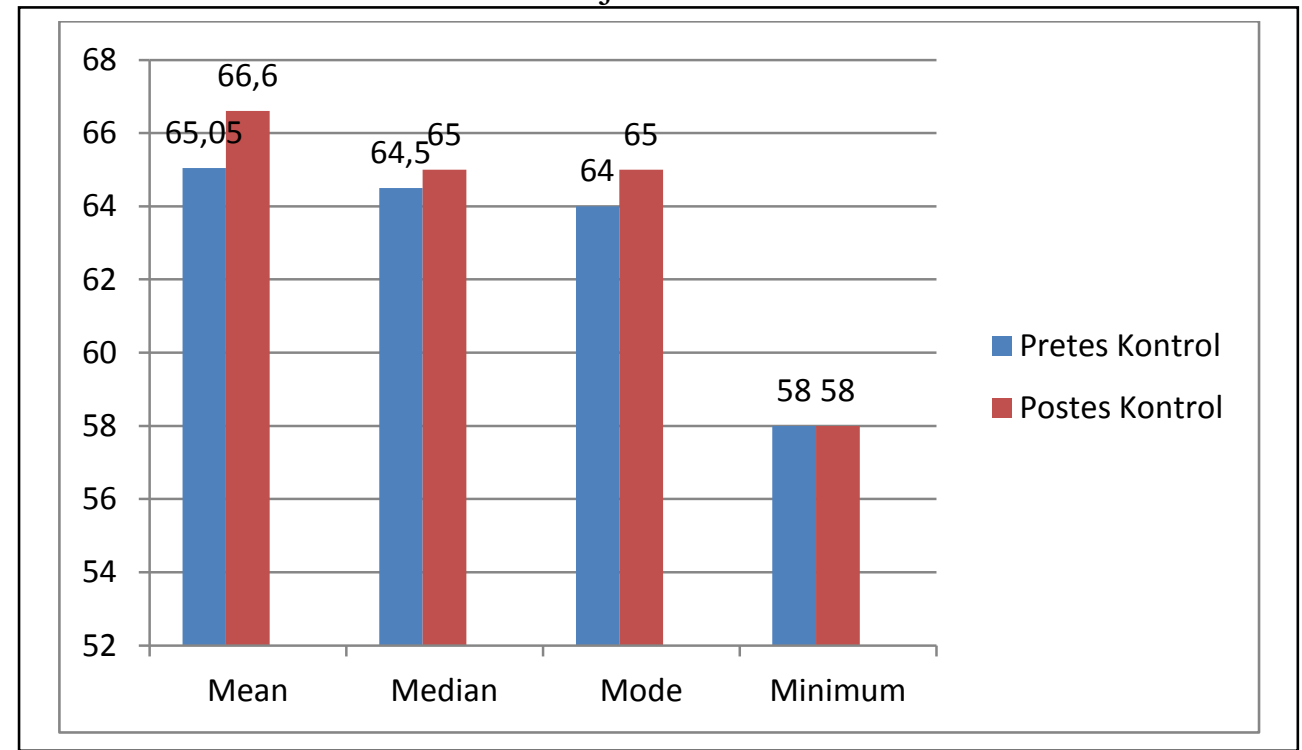


Dari grafik di atas dijelaskan bahwa hasil belajar kelas kontrol diperoleh bahwa mean atau rata-rata pretes sebesar 66,05 dan postes sebesar 66,6. Median pretes diperoleh sebesar 64,5 dan postes sebesar 65. Modus pretes didapat sebesar 64 dan postes sebesar 65, sementara itu nilai minimal pretes dan postes sama-sama sebesar 58. Jadi dapat disimpulkan bahwa terdapat peningakatan pada hasil belajar kelas kontrol sebelum diberi perlakuan dan sesudah diberi perlakuan media gambar sketsa dilihat dari grafik terdapat peningkatan hasil belajar menulis karangan deskripsi tetapi hanya beberapa persen saja kemudian untuk median tidak ada perubahan atau nilainya tetap sama.

Gambar 2

Hasil Belajar Kelas Eksperimen

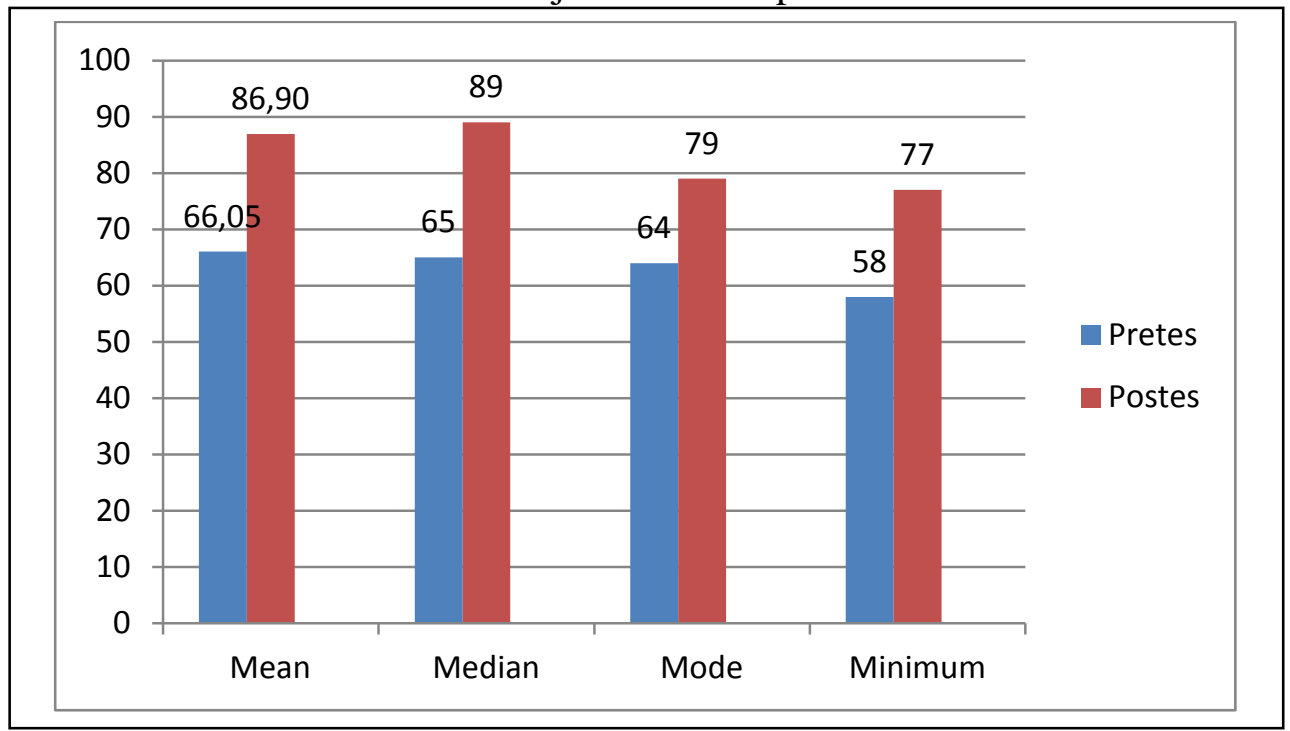

Dari grafik di atas dijelaskan bahwa hasil belajar kelas eksperimen pretes dan postes, dimana mean atau rata-rata pretes sebesar 66,04 dan postes sebesar 86,90 . Nilai median pretes diperoleh sebesar 65 dan postes sebesar 89. Sementara itu modus pretes didapat sebesar 64 dan postes 79. Sedangkan nilai minimal pretes sebesar 58 dan nilai postes sebesar 77. Hal ini berarti bahwa terdapat perbedaan pada hasil belajar kelas eksperimen sebelum dan sesudah diberi perlakuan media gambar sketsa. Sehingga dapat disimpulkan bahwa terdapat peningkatan hasil belajar menulis karangan deskripsi pada kelas eksperimen antara hasil prestes dan postes. 
2. Respon Siswa Terhadap Penggunaan Media Gambar Sketsa

Tabel 1

Rekapitulasi Hasil Angket Respon Siswa

\begin{tabular}{|c|c|c|c|c|c|}
\hline \multirow[b]{2}{*}{$\begin{array}{c}\text { No } \\
\text { item }\end{array}$} & \multicolumn{4}{|c|}{ Pilihan } & \multirow[b]{2}{*}{ Jumlah } \\
\hline & $\begin{array}{l}\text { Sangat } \\
\text { Setuju }\end{array}$ & Setuju & $\begin{array}{c}\text { Tidak } \\
\text { Setuju }\end{array}$ & $\begin{array}{c}\text { Sangat } \\
\text { Tidak } \\
\text { Setuju }\end{array}$ & \\
\hline 1 & $76,2 \%$ & $23,8 \%$ & $0,0 \%$ & $0,0 \%$ & $100 \%$ \\
\hline 2 & $0,0 \%$ & $0,0 \%$ & $38,1 \%$ & $61,9 \%$ & $100 \%$ \\
\hline 3 & $0,0 \%$ & $38,0 \%$ & $4,8 \%$ & $57,2 \%$ & $100 \%$ \\
\hline 4 & $0,0 \%$ & $9,5 \%$ & $52,4 \%$ & $38,1 \%$ & $100 \%$ \\
\hline 5 & $66,7 \%$ & $23,8 \%$ & $9,5 \%$ & $0,0 \%$ & $100 \%$ \\
\hline 6 & $0,0 \%$ & $0,0 \%$ & $42,9 \%$ & $57,1 \%$ & $100, \%$ \\
\hline 7 & $0,0 \%$ & $0,0 \%$ & $9,5 \%$ & $90,5 \%$ & $100 \%$ \\
\hline 8 & $4,8 \%$ & $4,8 \%$ & $81,0 \%$ & $9,4 \%$ & $100 \%$ \\
\hline 9 & $0,0 \%$ & $0,0 \%$ & $52,4 \%$ & $47,6 \%$ & $100 \%$ \\
\hline 10 & $0,0 \%$ & $33,4 \%$ & $9,5 \%$ & $57,1 \%$ & $100 \%$ \\
\hline 11 & $4,8 \%$ & $14,3 \%$ & $38,0 \%$ & $42,9 \%$ & $100 \%$ \\
\hline 12 & $38,1 \%$ & $47,6 \%$ & $14,3 \%$ & $0,0 \%$ & $100 \%$ \\
\hline 13 & $0,0 \%$ & $4,7 \%$ & $28,6 \%$ & $66,7 \%$ & $100 \%$ \\
\hline 14 & $4,8 \%$ & $33,3 \%$ & $42,9 \%$ & $19,0 \%$ & $100 \%$ \\
\hline 15 & $57,1 \%$ & $42,9 \%$ & $0,0 \%$ & $0,0 \%$ & $100 \%$ \\
\hline 16 & $47,6 \%$ & $47,6 \%$ & $4,8 \%$ & $0,0 \%$ & $100 \%$ \\
\hline 17 & $0,0 \%$ & $0,0 \%$ & $47,6 \%$ & $52,4 \%$ & $100 \%$ \\
\hline 18 & $0,0 \%$ & $0,0 \%$ & $42,9 \%$ & $57,1 \%$ & $100 \%$ \\
\hline 19 & $47,6 \%$ & $52,4 \%$ & $0,0 \%$ & $0,0 \%$ & $100 \%$ \\
\hline 20 & $52,4 \%$ & $42,9 \%$ & $4,7 \%$ & $0,0 \%$ & $100 \%$ \\
\hline Jumlah & $400,1 \%$ & $419,0 \%$ & $523,9 \%$ & $657,0 \%$ & $2000 \%$ \\
\hline $\begin{array}{c}\text { Rata- } \\
\text { rata }\end{array}$ & $20,1 \%$ & $20,95 \%$ & $26,20 \%$ & $32,85 \%$ & $100 \%$ \\
\hline
\end{tabular}

Berdasarkan keterangan dari tabel rekapitulasi di atas dapat dijelaskan bahwa hasil dari jawaban tentang respon siswa terhadap penggunaan media gambar sketsa dari pernyataan yang berkategori pernyataan positif dan pernyataan negatif rata-rata $(20,1 \%)$ menjawab sangat setuju, $(20,95 \%)$ menjawab setuju, $(26,20 \%)$ menjawab tidak setuju, dan $(32,85 \%)$ menjawab sangat tidak setuju.

Berdasarkan uraian item angket di atas, untuk mengetahui kuat tidaknya angket tersebut, maka peneliti melakukan analisis terhadap angket tersebut dengan menggunakan rating scale. Jumlah skor kriterum (apabila setiap item mendapat skor tertinggi) yaitu $=($ skor tertinggi tiap item $=4) \times($ jumlah item $=20) \times$ (jumlah responden $=21$ ) adalah 1680 . Pada rekapitulasi angket di atas jumlah skor hasil pengumpulan data $=2000$. Dengan demikian respon siswa terhadap media gambar 
sketsa menurut 20 responden, yaitu $1680: 2000 \times 100 \%=84 \%$ dari kriterium yang ditetapkan. Apabila diinterpretasi, nilai $84 \%$ terletak pada daerah sangat kuat. Artinya respon siswa terhadap media gambar sketsa baik karena siswa merasa terbantu dengan adanya media sketsa ketika mengarang deskripsi.

\section{Gambar 3}

Rekapitulasi Hasil Angket Respon Siswa

Terhadap Penggunaan media sketsa

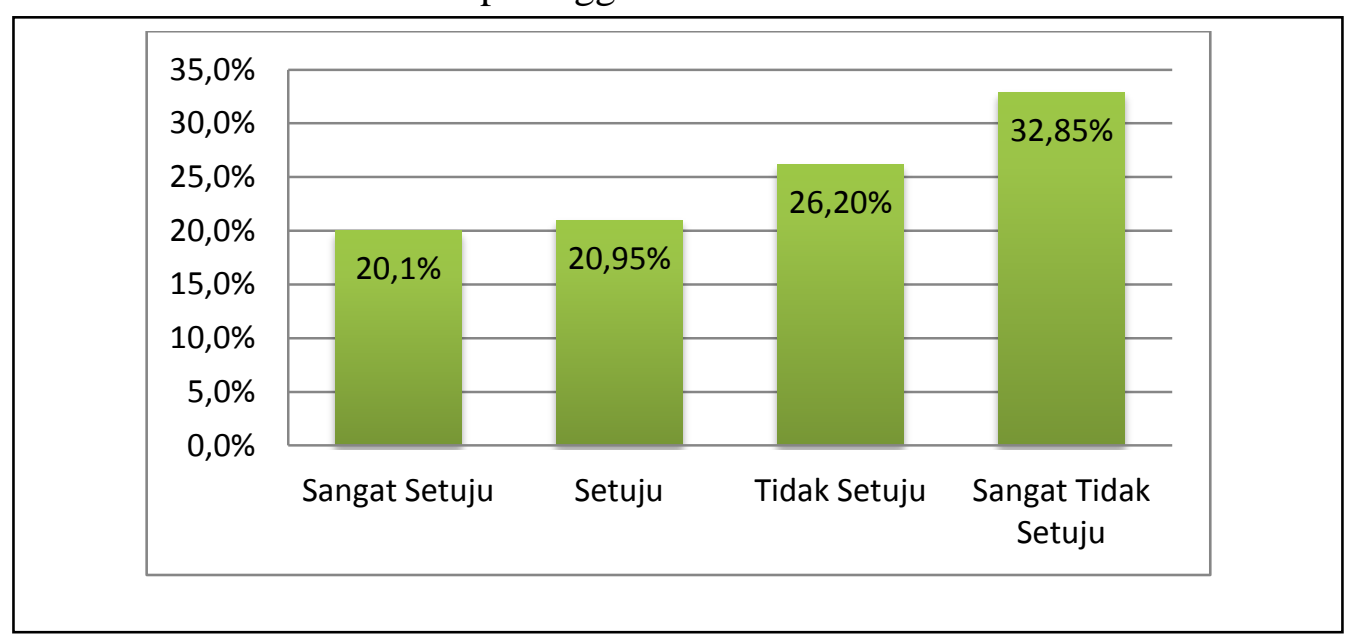

Dari grafik di atas dapat dijelaskan bahwa rekapitulasi angket positif dan negatif respon siswa terhadap penggunaan media sketsa, dimana siswa yang menjawab sangat setuju sebesar $20,1 \%$, siswa yang menjawab setuju $20,95 \%$, siswa yang menjawab tidak setuju sebesar 26,20 dan siswa yang menjawab sangat tidak setuju sebesar 32.85.

Artinya keseluruhan dari angket respon siswa terhadap hasil belajar menulis karangan bahwa siswa menjawab sangat setuju pada pernyataan angket no (1). Siswa merasa senang menulis karangan deskripsi dengan menggunakan media gambar sketsa, (3) Siswa merasa lebih mudah menulis karangan deskripsi dengan menggunakan media gambar sketsa. Siswa menjawab pernyataan setuju pada item angket no (11) Ketika pembelajaran menggunakan media gambar sketsa siswa bisa bertukar pikiran dengan teman. (15) Siswa mudah menulis karangan deskripsi dengan menggunakan media gambar sketsa siswa menjawab tidak setuju pernyataan no (13) Siswa mampu menulis karangan deskripsi dengan ejaan yang baik tanpa menggunakan media gambar sketsa. (8) Dengan menggunakan media gambar sketsa membuat suasana kelas tidak menyenangkan dan siswa yang menjawab pernyataan tidak setuju pernyataan no (5) Penggunaan media gambar sketsa dalam menulis karangan deskripsi membosankan. (12) Siswa tidak tertarik untuk mengikuti pelajaran bahasa Indonesia materi karangan deskripsi dengan menggunakan media gambar sketsa. Dalam pernyataan angket tidak 
setuju dan sangat tidak setuju disini bahwa siswa merespon angket dari pernyataan negatif sehingga siswa banyak menjawab tidak setuju dan sangat tidak setuju dalam pernyataan angket negatif tersebut.

3. Pengaruh Penggunaan Media Gambar Sketsa Terhadap Hasil Belajar Menulis Karangan Deskripsi

\section{Uji regresi}

Tabel 2

Model Summary

\begin{tabular}{|c|r|r|r|r|}
\hline Model & R & R Square & \multicolumn{1}{|c|}{$\begin{array}{c}\text { Adjusted R } \\
\text { Square }\end{array}$} & $\begin{array}{c}\text { Std. Error of the } \\
\text { Estimate }\end{array}$ \\
\hline 1 & $.754^{\mathrm{a}}$ & .568 & .546 & 4.09948 \\
\hline
\end{tabular}

a. Predictors: (Constant), media gambar sketsa

Pada tabel di atas terdapat R Square sebesar 0,568 (kuadrat dari koefisien korelasi 0,754). R Square disebut koefisien determinan yang dalam hal ini 56,8\%. Dari harga tersebut dapat diartikan bahwa $56,8 \%$ pengaruh penggunaan media gambar sketsa terhadap hasil belajar menulis karangan deskripsi siswa kelas V MIN Kota Cirebon sedangkan sisanya dipengaruhi oleh faktor lain.

\section{Uji Hipotesis}

Tabel 4

Coefficients $^{\mathrm{a}}$

\begin{tabular}{|c|c|c|c|c|c|}
\hline \multirow[t]{2}{*}{ Model } & \multicolumn{2}{|c|}{$\begin{array}{c}\text { Unstandardized } \\
\text { Coefficients } \\
\end{array}$} & $\begin{array}{c}\text { Standardized } \\
\text { Coefficients }\end{array}$ & \multirow[t]{2}{*}{$\mathbf{T}$} & \multirow[t]{2}{*}{ Sig. } \\
\hline & $\mathrm{B}$ & Std. Error & Beta & & \\
\hline (Constant) & -13.145 & 20.022 & & -.657 & .519 \\
\hline media gambar sketsa & 1.450 & .290 & .754 & 5.002 & .000 \\
\hline
\end{tabular}

Setelah megetahui besarnya koefisien regresi, maka perlu dilakukan pengujian hipotesis untuk megetahui apakah terdapat pengaruh atau tidak. Uji hipotesis dapat dinyatakan dengan membandingkan nilai signifikan yaitu

Jika nilai signifikan $>0,05$ dan $\mathrm{t}_{\text {hitung }}<\mathrm{t}_{\text {tabel }}$, maka $\mathrm{H}_{0}$ diterima

Jika nilai signifikan $<0,05$ dan $\mathrm{t}_{\text {hitung }}<\mathrm{t}_{\text {tabel }}$, maka $\mathrm{H}_{0}$ ditolak

Jika $t_{\text {tabel }}$ dicari dengan $\alpha=0,05$ dan (df) $n-k-1$ atau 21-2-1 $=17$, jadi $t_{\text {tabel }}=2.10982$

Berdasarkan hasil uji regresi di atas nilai signifikan sebesar 0,000. Karena nilai signifikan lebih kecil dari 0,05 dan t hitung $(5,002)$ lebih besar dari t tabel $(2.10982)$ maka Ho ditolak, artinya bahwa ada pengaruh media gambar sketsa terhadap hasil belajar menulis. 


\section{SIMPULAN}

Berdasarkan hasil penelitian yang dilaksanakan di kelas V MIN Kota Cirebon, penulis dapat mengambil kesimpulan sebagai berikut:

1. Hasil belajar siswa dengan media gambar sketsa pada mata pelajaran Bahasa Indonesia kelas V di MIN Kota Cirebon, dilihat dari hasil postes kelas eksperimen yang menerapkan media gambar sketsa diperoleh nilai rata-rata sebesar 86,9 dan hasil postes kelas kontrol diperoleh nilai rata-rata sebesar 66,6 artinya bahwa terdapat perbedaan hasil belajar kelas eksperimen yang menerapkan media gambar sketsa dan kelas kontrol yang tanpa menggunakan media sketsa.

2. Respon siswa terhadap penggunaan media gambar sketsa pada mata pelajaran Bahasa Indonesia kelas V di MIN Kota Cirebon diperoleh bahwa siswa memberikan respon yang baik, siswa menerima dan senang dengan penggunaan media sketsa, hal ini terbukti dengan hasil penyebaran angket pada 21 siswa kelas eksperimen dengan persentase angket positif sebesar $88,6 \%$ tergolong pada kategori sangat kuat berada diantara $81 \%$ - 100\%. Persentase angket negatif sebesar 83,9\% tergolong pada kategori sangat kuat berada diantara $81 \%$ - 100\%. Persentase $83,9 \%$ angket negatif tersebut artinya siswa sangat kuat menolak pernyataan angket negatif secara tidak langsung persentase 83,9\% angket negatif itu juga mendukung pernyataan angket positif, dengan kata lain berarti siswa senang dan antusias belajar dengan menggunakan media gambar sketsa. Sedangkan rekapitulasi angket positif dan negatif sebesar $84 \%$ tergolong pada kategori sangat kuat berada diantara $81 \%-100 \%$. Artinya respon siswa terhadap media gambar sketsa baik karena siswa merasa lebih mudah menulis dengan media gambar sketsa.

3. Pengaruh penggunaan media gambar sketsa terhadap hasil belajar menulis karangan deskripsi siswa kelas V di MIN Kota Cirebon, berdasarkan hasil pengujian diperoleh R Square sebesar 0,568 (kuadrat dari koefisien korelasi 0,754). R Square disebut koefisien determinan yang dalam hal ini 56,8\% . Dari nilai tersebut dapat diartikan bahwa $56,8 \%$ pengaruh penggunaan media gambar sketsa terhadap hasil belajar siswa sedangkan sisanya dipengaruhi oleh faktor lain. Pada hasil uji regresi di peroleh hasil uji t hitung sebesar 5,002 dengan nilai signifikan sebesar 0,000. Karena nilai signifikan lebih kecil dari 0,05 dan thitung (5,002) lebih besar dari t tabel (2.10982) maka dapat disimpulkan bahwa Ho ditolak, artinya bahwa ada pengaruh media gambar sketsa terhadap hasil belajar menulis karangan deskripsi Sedangkan sisanya dipengaruhi oleh faktor lain. 


\section{DAFTAR PUSTAKA}

Arsyad, Azhar. 2013. Media Pembelajaran. Jakarta : Rajawali pers.

Arikunto, Suharsimi. 2012. Dasar-Dasar Evaluasi Pendidikan (Edisi ke-2). Jakarta: Rineka Cipta.

Dalman. 2015. Ketrampilan Menulis. Jakarta : Rajawali pers.

Guntur Tarigan, Henry. 2008. Menulis Sebagai Suatu Keterampilan Berbahasa. Bandung: Angkasa Group

Riduwan dan Sunarto. 2007. Pengantar Statistika. Bandung: Alfabeta. Rosdakarya

Sugiyono. 2015. Metode Penelitian, Pendekatan Kuantitaf, kualitatif, dan R\&D.Bandung: Alfabeta

.2012. Metode Penelitian, Pendekatan Kuantitaf, kualitatif, dan $R \& D$. Bandung: Alfabeta 